\title{
TO FIND OUT THE STATUS OF VITAMIN D, HIGH DENSITY LIPOPROTEIN \& TRIGLYCERIDES (TG) IN PATIENT OF TYPE 2 DM
}

\section{Dr. Ashish Shukla*}

\section{Dr Richa Sirohi}

Associate Professor Flat No 39, Sant Ravidas Bhawan R, Enclave, Subharti Medical College Subharti University, Meerut,UP 250005. ${ }^{*}$ Corresponding Author

Assistant Professor, Department Of Biochemistry, Subharti Medical College, Meerut

ABSTRACT Vitamin D Deficiency Is Consider To Be one Of The Immersing Health issues due To Lack Of Sun Exposure And Other Life Style Moderation, Various Research Studies Have Proposed it's extra skeletal role in maintaining Cardiovascular profile and promote insulin activity. AIM: To Find Out the status of Vitamin D, HDL,TG and blood glucose level In patient of TYPE 2 DM MATERIAL \& METHOD: Our Hospital Based observational Study Was Conducted on 100 subjects. RESULT: Significant variation found in levels of vitamin D and lipid profile parameters in patients of type 2 DM. CONCLUSION: A randomized control study with a large population size will be better in consolidating the role of vitamin $\mathrm{D}$ in cardiovascular and metabolic disorders.

\section{KEYWORDS : Vitamin D, Type 2Diabetes Mellitus, lipid profile}

INTRODUCTION: Type 2 Diabetes Mellitus (T2DM) is a major metabolic disorder that has become increasingly prevalent. ${ }^{1.2}$ The number of people suffering from diabetes is expected to become more than double by 2030 from 171 million to an astonishing 366 million people worldwide, with $90 \%$ of them suffering from T2DM.Dihyroxy -cholecalciferol or vitamin D is a fat soluble vitamin with its prime role in maintaining calcium homeostasis and skeletal stability but in current scenario the extra skeletal role of vitamin D is well proven specially in terms of modulation of immune function and inflammation, insulin secretion, cardiovascular protection, and gene expression ${ }^{3.4}$ Many observational studies and clinical trials have confirmed the direct role of vitamin $\mathrm{D}$ in regulation of blood glucose and healthy levels of biochemical lipid profiles. The association between vitamin $\mathrm{D}$ and cardiovascular disease could be explained by a lipid-lowering effect of vitamin D. This has been substantiated in various Meta analysis and cross- sectional studies, and there is a general agreement that high serum $25(\mathrm{OH})$ D levels are associated with a favorable serum lipid profile.5-7, other than that vitamin $\mathrm{D}$ act via both genomic and non-genomic pathways and $t$ effects on insulin secretion, -cell function, and insulin resistance $[8,9]$.

MATERIAL \& METHOD: A hospital based study was carried out by department of biochemistry, subharti medical college in association with medicine OPD of chatrapati shivaji subharti hospital, meerut, UP, india, after obtaining ethical clearance from institutional ethical committees, study was carried out for a period of one year. Study was conducted on 100 subjects, among that 50 were cases of type $2 \mathrm{DM}$ and 50 were healthy control. Exclusion criteria included pregnancy, lactation, use of drugs affecting the lipid profile or calcium and bone metabolism, chronic disorders of the liver or kidney, endocrinology disorders such as hypo- or hyperthyroidism and hyperparathyroidism, smoking, insulin injection, use of anticonvulsive drugs, and vitamin D or calcium supplementati on.

All participants were subjected to anthropometric measurements including height, weight and abdominal circumference and their fasting blood sugar, High Density Lipoprotein (HDL) and triglycerides (Tgs), vitamin D level were done by standard procedures.

Vitamin D level was estimated by ADVIA Centaur Vitamin D assay which is an 18-minute antibody competitive immunoassay, estimation of fasting blood sugar, HDL and TGs were done on Siemens dimension auto analyzer.

\section{STATISTCAL ANALYSIS}

Data was analysed by unpaired student $t$ test. Values were given as mean $\pm \mathrm{SD}$. P value of $<0.001$ was considered as significant

RESULTS: Our study was conducted on 100 subjects, 50 were diagnosed cases of type 2DM and 50 were healthy controls, statistically significant alteration was found in levels of $25(\mathrm{OH}) \mathrm{D}$ in patient of type $2 \mathrm{DM}$ with mean $\pm \mathrm{SD}$ value was $11.32 \pm 3.88$ as compared to control group. No significant observation was observed in values of HDL in between cases and control group but values of TGs were significantly raised in cases of type $2 \mathrm{DM}$ as compared to control group.

\begin{tabular}{|l|l|l|l|}
\hline Parameters & Case & Control & P value \\
\hline $\begin{array}{l}25(\mathrm{OH}) \mathrm{D} \\
(\mathrm{nmol} / \mathrm{L})\end{array}$ & $11.32 \pm 3.88$ & $38.60 \pm 5.23$ & $<0.01$ \\
\hline $\mathrm{HDL}(\mathrm{mg} / \mathrm{dl})$ & $40.21 \pm 4.29$ & $43.46 \pm 4.65$ & $>0.05$ \\
\hline TG $(\mathrm{mg} / \mathrm{dl})$ & $165.52 \pm 8.48$ & $122 \pm 5.46$ & $<0.01$ \\
\hline FBS $(\mathrm{mg} / \mathrm{dl})$ & $152 \pm 7.34$ & $77 \pm 6.54$ & $<0.01$ \\
\hline $\mathrm{HbAlc}$ & $7.45 \pm 0.67$ & $4.26 \pm 0.23$ & $<0.01$ \\
\hline
\end{tabular}

The anthropometric measurements of the subjects of both cases $(n=50)$ and control $(n=50)$. Diastolic blood pressure, systolic blood pressure, waist circumference \& BMI showed marked difference and were statistically significant.

\section{TABLE 2: ANTHROPOMETRIC PARAMETERS OF CASE AND} CONTROL

\begin{tabular}{|l|l|l|l|l|l|l|}
\hline \multirow{2}{*}{$\begin{array}{l}\text { Anthropometric } \\
\text { Parameters }\end{array}$} & CASE & \multicolumn{2}{l|}{ CONTROL } & P -value & S/NS \\
\cline { 2 - 6 } & $\mathbf{n = 5 4}$ & $\mathbf{n}=\mathbf{5 3}$ & & & & \\
\cline { 2 - 5 } & MEAN & SD & MEAN & SD & & \\
\cline { 3 - 5 } & & \pm & & \pm & & \\
\hline AGE(yrs) & 43.4 & \pm 11.9 & 38.6 & \pm 12.8 & .049 & NS \\
\hline WAIST(cm) & 100 & \pm 9.9 & 87.6 & \pm 10.6 & $<0.001$ & S \\
\hline BPsystolic & 137.4 & \pm 12.7 & 126.2 & \pm 15.7 & $<0.001$ & S \\
\hline BPdiastolic & 88.8 & \pm 13.2 & 81.3 & \pm 9.7 & $<0.001$ & S \\
\hline BMI(kg/m2) & 28.2 & \pm 4.4 & 24.3 & \pm 4.5 & $<0.001$ & S \\
\hline
\end{tabular}

\section{DISCUSSION:}

Our study was conducted on 50 diagnosed cases of type $2 \mathrm{DM}$ and compared our results with 50 healthy controls. We had observed significant alteration in levels of Vitamin D in cases of diabetes mellitus type 2 as compared to healthy controls; 
our study findings were corresponding to the finding of Daga et al were they reported that $91.1 \%$ of diabetic subject had vit D insufficiency $91.1 \%$ of diabetic patients had vit D insufficiency. In their study vit-D concentration in diabetic patients was $7.88 \pm 1.2$, however, in non-diabetic individuals, it was 16.64 1.83 . we have also observed a significant association in between levels of TGs AND vit D in cases of DM as compared to controls; Ford and colleagues, in their NHANES III study, found a negative association between serum levels of $25(\mathrm{OH}) \mathrm{D}$ and TG in patients with hypertriglyceridemia. However, this relationship was not observed with regard to HDL cholesterol in healthy subjects [21]

\section{REFERENCES:}

1. International Diabetes Federation. Diabetes: facts and figures. IDF. 2014. Accessed July 8, 2014, at, www.idf.org/worlddiabetesday/toolkit/gp/factsfifigures.

2. Jafari T, Fallah AA, Azadbakht L. Role of dietary n-3 polyunsaturated fatty acids in type 2 diabetes: a review of epidemiological and clinical studies. Maturitas 2013;74:303e8.

3. Jafari T, Faghihimani E, Feizi A, Iraj B, Javanmard SH, Esmaillzadeh A, et al. Effects of vitamin D-fortifified low fat yogurt on glycemic status, anthropo metric indexes, inflflammation, and bone turnover in diabetic postmenopausal women: a randomised controlled clinical trial. Clin Nutr 2016;35:67e76.

4. Jafari T, Paknahad Z. Vitamin D and hypertension. Zahedan J Res Med Sci 2014;16:1e7.

5. Jorde R, Figenschau Y, Moira Hutchinson M, Emaus N, Grimnes G. High serum 25-hydroxyvitamin D concentrations are associated with a favourable serum lipid profile. Eur J Clin Nutr. 2010;64:1457-1464.

6. Jorde R, Grimnes G. Vitamin D and metabolic health with special reference to the effect of vitamin D on serum lipids. Prog Lipid Res. 2011;50:303-312.

7. Zittermann $\mathrm{A}$, Gummert JF, Bo" rgermann J. The role of vitamin D in dyslipidemia and cardiovascular disease. Curr Pharm Des. 2011;17: 933-942.

8. Zeitz U, Weber K, Soegiarto DW, Wolf E, Balling R, Erben RG: Impaired insulin secretory capacity in mice lacking a functional vitamin D receptor. FASEB J 2003, 17(3):509-5

9. Chiu KC, Chu A, Go VLW, Saad MF: Hypovitaminosis D is associated with insulin resistance and cell dysfunction. Am J Clin Nutr 2004, 79(5):820-825

10. Daga RA, Laway BA, Shah ZA, et al. High prevalence of vitamin D deficiency among newly diagnosed youthonset diabetes mellitus in north India. Arq Bras Endocrinol Metabol 2012; 56: 423-8.

11. Ford ES, Ajani UA, McGuire LC, Liu S: Concentrations of serum vitamin D and the metabolic syndrome among US adults. Diabetes Care 2005, 28(5):1228-1230. 